\title{
About the Authors
}

\author{
Music \& Politics \\ Volume 9, Number 1 \\ Winter 2015
}

Anabela Duarte is a postdoctoral researcher. She holds a $\mathrm{PhD}$ in American studies with a thesis on Paul Bowles' literature and music from a cross-cultural perspective. She has a BA and an MA in anthropology and an MA in comparative literature. She publishes in Brill/Rodopi, Music E Politics, cultural journals and art magazines. She's a singer, sound maker and performer. Duarte is a researcher at ULICES (University of Lisbon Center for English Studies).

http://ulices.academia.edu/AnabelaDuarte

http://www.ulices.org/g3-estudos-americanos/anabela-fernandes-duarte.html

Dalton Anthony Jones is an assistant professor in the School of Cultural and Critical Studies at Bowling Green State University where he teaches courses in black studies, ethnic studies, American culture studies and peace and conflict studies. Broadly speaking, he is a cultural economist and historian whose work focuses on emotional labor in relation to questions of identity, language (modes of articulation and expression), political authority, race, and social power.

Stephen R. Millar is a PhD candidate in ethnomusicology at Queen's University Belfast and previously worked as a researcher on the "Community Experiences of Sectarianism" project at the University of Stirling. His scholarly interests stretch from poetry and song in the Age of Revolution to contemporary conflicts involving music, ethno-nationalism and identity politics; he is particularly interested in the use of Loyalist and Republican music in Britain, Ireland, and the United States.

Cornelia Nuxoll studied Social Anthropology and Religious Studies in Marburg, London and Berlin and a completed a postgraduate course on sustainable development. She conducted fieldwork in Burkina Faso, Mali and Sierra Leone and until recently, she was a research assistant with the research group "Music, Conflict and the State" at the Georg-University of Göttingen in Germany. She is currently in the completion phase of her doctoral thesis on the role of music among juvenile RUF combatants during the Sierra Leonean war.

Rachel Orzech is a doctoral student and casual staff member at the Melbourne Conservatorium of Music, University of Melbourne (Australia). Her Masters thesis examined Jewishness in the reception of Fromental Halévy's 1835 grand opera La Juive, and her doctoral research focuses on the reception of Wagner in Paris in the 1930s and 40s. Rachel is undertaking her PhD as a co-tutelle with the University of Rouen in France, and in 2014 she was awarded an Endeavour Research Fellowship to pursue her research in Paris. Her research interests include opera studies, Jewish studies, Wagner, reception studies, nineteenth- and twentieth-century French musical life and the intersection of music and politics. 